The Alberta Court quoted with approval a passage from Farnsworth v. Garrard $^{44}$ (which was followed in Dakin v. Lee) to the effect that:45

... if some benefit has been derived, though not to the extent expected, this should go to the amount of the plaintiff's demand, leaving the defendant to his action for negligence.

The Alberta Court then went on, in the manner of the celebrated headnote to the Dakin case, to consider whether the defect in work in that case had been so bad that the recipient of the work had derived no benefit from it. This was found to be the case. If substantially defective work entitled one to no compensation, it would not have been necessary to go through that exercise.

It is therefore apparent that the previous English authorities as well as the Canadian authorities are unanimous in distinguishing between incomplete performance and defective performance awarding reduced compensation for the latter.

In any court which is not bound by any of these decisions, which result should be followed? It is submitted that there can be no argument as to this point. Why should the recipient of defective but valuable work be able to take the benefit of it without paying any part of the price? If a man has a $\$ 1,000.00$ garage built on his property which is defective to the amount of $\$ 200.00$, why should he get it free? He can either live with the defects (if he wishes to save $\$ 200.00$ ) or he can easily find another builder who will put them right for $\$ 200.00$. On either view the work done is worth $\$ 800.00$ to him. In neither event does there seem to be any justification in logic, morals, or social planning for depriving the builder of all his charges.

Indeed that is the strangest aspect of the recent English decision: 45 Why was the Court of Appeal at such pains to deprive the builder of all his remuneration?

-J. E. COTE*

" (1807) Camp 38; 170 E.R. 867.

is Bolton v. Mahadeva, supra, n. 2.

- B.A., LL.B., B.C.L., of the Alberta Bar. Copyright retained by the author.

\title{
THE ELEMENTS OF A TORRENS TITLE
}

The anatomy and physiology of the body of Torrens statute and case law is incredibly complex. There are perhaps three reasons for this. Firstly; the originator of this most valuable system may not have possessed a legal acumen commensurate with his reforming zeal. Secondly, the system-initially expressed in aliodal terms ${ }^{1}$ - was imposed upon an established body of laws which was and is not always compatible with it. Thirdly, those who have administered and interpreted the system in the courts have not always been receptive to its innovations nor, with respect, clear in their conception of its meaning. The latter, in view of the drafting and composition of the respective versions of the system, is easy to understand and forgive. ${ }^{2}$

Due to this complexity an analysis of any aspect of the system is

1 Hogk, Australian Torrens System 3 (1905).

3 Id. at 24. 
liable to become bogged down in, if not muddled by, the complexities which are very soon encountered. While no one area of a system can be properly considered in ignorance of all the rest-for the very reason that the whole is a system-the most valuable means of analysis seems to be to approach each of the vital concepts of the system by as direct a route and in as isolated a manner as possible. By this means the leading issues can be understood in their essence with as little confusion as possible. When grasped at this level they can be then more readily interrelated and systematized; or the impossibility of interrelation and systematization of the present provisions can then be more easily seen. With great respect, I suggest that the great defect of title registration as a system is the confusion of the parts.

This paper will focus on the nature of the elements of a title to land under a Torrens system. The matters thus surveyed of course involve such questions as the corrective powers of the registrar, the assurance fund as the back-up to the state guarantee, and the very nature of a registered estate itself. This total framework must be kept in mind throughout; but for the reasons noted above it will not be given detailed consideration here.

\section{TORRENS: GENESIS}

In works on the title registration system which attempt to sound some of its more deep and difficult provisions, recollections back to the original works of Sir Robert Torrens occur with worthwhile frequency. As acceptable as such groundwork may be, however, a perusal of Torrens' ideas must be undertaken with caution. Aside from the fact that his writings may, in places, be as unsusceptible of interpretation as parts of the statute, there are three factors which may render them inconclusive or even misleading.

Firstly, it should be remembered that Torrens' work itself grew in the soil of conceived necessity. "Twenty-two years have now elapsed" he wrote in 1859 "since my attention was first painfully drawn to the grievous injury and injustice inflicted by the English law of Real Property, by the misery and ruin which fell upon a relation and dear friend who was drawn into the maelstrom of the Court of Chancery, and I then resolved some day to strike a blow at that iniquitous system". Translated in the more than personal needs of the general community, the avowed need to be fulfilled by the first Torrens statute was to save the inhabitants of South Australia from the: ${ }^{4}$

... losses, heavy costs and much perplexity by reason that the laws relating to the transfer and encumbrance of freehold and other interests in land are complex, cumbrous, and unsuited to the requirements of the inhabitants.

It is manifest that societies' needs are not static; and while the ends which Torrens hoped to achieve are commendable, his motivations and methods may not now be strictly relevant due in part, it is true, to Torrens himself.

The second reason for using caution in applying the Torrens genesis is that the original enactments of his concepts were subject to rapid

\footnotetext{
3 Fox, The Story Behind the Torrens System, (1956) 23 Aust. L.J. 489 at 490 . Unfortunately Torrens' original work, The South Australian System of Conveyancing by Registration of Title, was not available in primary form.

- South Australian Real Property Act (1858) 21 Vict. No. 15.
} 
change. The first title registration statute was passed in South Australia in July of 1858.5 By December of the same year the Real Property Law Amendment Act ${ }^{6}$ almost totally re-drew the measure-repealing seventy complete sections and parts of others and replacing them with substantially different provisions. ${ }^{7}$ A consolidating statute, which also further amended the original act, was passed in 1860.8 After the convening of a committee of inquiry with Torrens as a member, but not chairman, the Real Property Act of $1861^{9}$ was produced and was more or less the final product. The result was a system quite different in many respects from that first put forward by Torrens; ${ }^{10}$ and it was this amended system which was received in other jurisdictions.

Finally, many of the ambiguities and discrepancies in the legislation have been subject to interpretation and reconciliation by the courts. To attempt to evaluate or understand the cases using Torrens as a template may be a rather unrealistic appraisal of the judicial process. Courts which are not entitled to examine the records of Parliament ${ }^{11}$ to assess the meaning of a statute can really not be expected to peruse the mind of the colonial reformer other than manifested within the four corners of the Act. The courts may, of course, receive what Torrens had to say as a suggestion of meaning, but the final determination must be of what the statute says, not what Torrens said.

Thus, it is suggested that although Torrens as a genesis ought to be examined, it must be with caution more than reverance. It is further suggested that the understanding of the Alberta Land Titles Act should proceed, in unconcluded areas, from a conception of the needs of our place and time. History should not be permitted to make the present formulation of a very desirable system sacred. As Professor Thompson has pointed out, we have perhaps suffered enough from the rubric of capsuled oratory, and require further realization that the mere name "Torrens System" is no magic. ${ }^{12}$ Ruoff has suggested as "remarkable that after nearly [then] one hundred years no substantial amendments have been made in Torrens' original measure". ${ }^{13}$ This may be even more remarkable than it at first blush appears, for land titles is "a vital subject in which statutory reform is not merely an ideal but a necessity".14

\section{THE "INIQUITOUS SYSTEM"}

If there is such a thing as an indefeasible title it must be one which is unimpeachable; unexaminable; conclusive; incontrovertible. ${ }^{15}$ Whatever the case now, certain it is that under the original English system, few titles if any could lay claim to indefeasibility.

Of the many attacks which could be made against a right to land in

5 Id.

- Real Property Law Amendment Act (1958) 22 Vict. No. 16.

7 Harrison, The Transformation of Torrens's System into the Torrens System, (1961) 4 Univ. of Queensland L.J. 125. This is a presentation of the nature of the legislative changes.

- Real Property Act (1860) 23 \& 24 Vict. No. 11.

- Real Property Act (1861) $24 \& 25$ Vict. No. 22.

10 Harrison, supra, n. 7 at 25.

"Kilgour. The Rule ARainst the Use of Legislative History, (1952) 30 C.B. Rev. 769 at 772.

12 Thompson, The Course in Land Titles at the University of Alberta, (1964) 3 Alta. L. Rev. 117 at 120.

13 Ruoff, An Englishman Looks at the Torrens System 7 (1957).

14 Thompson, supra, n. 12 at 122.

is Woodman, The Torrens System in new South Wales: One Hundred Years of Indefeasibility, (1970) 44 Aust. L.J. 96. 
the deed system, two major, if not exclusive, objectives may be broached. Firstly a title could be impugned if it were shown that its holder had not acquired it from one who had good root. Good root under that system was "a document purporting to deal with the entire legal and equitable estate and interest in the property, not depending for its validity upon any previous instrument, and containing nothing to throw any suspicion on the title of any of the disposing parties". ${ }^{16}$ To attempt to insure that he was getting a good title a purchaser was compelled to examine the documents of disposition of the title, tracing its devolution from the root to the deed of the vendor. An immediate grant from the Crown, or a transfer from one who held by immediate grant, was simple and safe enough. If there were a number of intervening transactions, however, with the validity of a transferee's title dependent upon the validity of each of them, the task became tedious, difficult, and expensive. It was also very unsafe because the title could yet be impugned by a successful attack, until then not pressed, on any prior title. No person could take better than his predecessor had to give.

It was also necessary that the deed by which the purchaser took the title from his vendor be in proper form and execution. If it was not, through mistake, or incapacity, or forgery, or lack of completion, no title was transferred.

Of these two features, it was the former which debilitated the law of title transfer. Hogg notes that "the retrospective deduction of title ... [is] the great practical grievance of the [old] law of real property". ${ }^{17}$ It was this defect which Torrens spent his energy upon. After cataloging a list of defects in the prior law, he directly states that in his view they "have all a common source-"The dependent nature of titles" ".18

\section{OF SHIPS}

An officer with the Indian Army who was a friend, and perhaps also a cousin of Torrens, purchased a parcel of land in India. He expended $£ 20,000$ in improving it-cultivating plantations and undertaking construction. Although the legal title to the property was in order, it seems that the title of his friend's vendor was subject to some equitable right of which the unfortunate purchaser was deemed to have notice. As a consequence the land and all improvements were lost.

It appears that this circumstance stirred Torrens to a vituperative zeal: 19

The present system (of conveyancing) has grown out of ingenious devices to evade the oppressions of feudal tyrants, but under it we are subject to the tyranny of the legal profession and burdens little less grievous.

They (lawyers) love the mysteries, which they have spent so much time in learning, and they do not like the rude hand which would wipe away the cob-webs, in spinning which they have spent their zeal, their days, for perhaps half a century.

Fortunately Torrens did not limit himself to castigation of the system. He was determined to improve it. For many years Torrens had been a collector of customs. When he was later appointed Registrar of Deeds in 1853 his ideas began to crystallize. Legend has it that his experience

16 Williams, Contract for Sale of Land and the Title to Land 534 (3rd ed. 1966).

17 Hogg, supra, n. 1 at 17.

18 Harrison, supra, n. 7 at 125.

19 Fox, supra, n. 3 at 489. 
with the regulation of commercial shipping was brought to bear on his fermenting resolve to perfect land law, which he was now learning in more detail through his work in the registry office. It certainly does appear that when Torrens saw that he could, he seized upon the solutions to problems in shipping titles and applied them to titles in land. "The South Australian system" he later wrote, "has been considered experimental only in that it applies to land methods of dealing which abundant experience has shown to be effectual and completely satisfactory when applied to property in shipping ...."20

Thus, although it can be said that Torrens' methods were original only in their application, the revolutionary character of that application ought not to be minimized. Unfortunately, the fact that Torrens probably envisaged the application as simpler than it really was ought not to be minimized either. So easy a transposition did Torrens seem to contemplate that a comparison of Torrens' 1858 Act with the Merchant Shipping Act of 1854 shows many of the provisions to be strikingly similar and many others identical. ${ }^{21}$ Indeed, the courts in a number of cases have gone so far as to interpret some of the Land Titles Act provisions in light of the Shipping Acts ${ }^{22}$ and although the practice has been criticized $^{23}$ it appears to be established. ${ }^{24}$

\section{THE GOAL}

Torrens' objective was to achieve a system of methods that would be suited to the needs of the community and which would be simple, inexpensive, and fast, while at the same time giving a secure and accurate title. Not all of these objectives are mutually compatible and, as will be explained later, there are resulting compromises in the system which must be taken into account.

The germ of Torrens' plan may be found in the following statement which appeared in the 1859 essay in which he described and explained his ideas: ${ }^{25}$

Indefeasibility is indespensible if the dependent or derivative character of titles, out of which, as has already been demonstrated, all the evils of the English system of conveyancing originate, is to be got rid of....

To this end, the registered title was to be conclusive (of either title, or root of title-which, exactly, is in dispute). There were also some supportive principles to which reference must be made.

At the occasion of the introduction of his private member's bill on 4 June 1857, Torrens alluded to two key concepts. As often as the fee simple was transferred, he said, the title must be surrendered and a fresh grant issued. Also, only by registration could land dealings validly be concluded.26 Torrens also indicated that should any person be deprived of land through the operation of these other principles, the system was still acceptable because such a person would be compensated by a fund established through the taxation of those using the system. ${ }^{27}$

${ }^{20}$ ld. at 492 .

"Id.

32 Robinson v. Coalcliff Co. (1891) 12 N.S.W. Eq. 315 at 318; Black v. Williams (1893) 1 Ch. 408.

23 Cuthbertson v. Swan (1877) 11 S.A.R. 102; In Re Wildash Q.L.R. Pt. II 47.

24 Bray v. McDonald (1867) i S.A.R. 22; Gibbs v. Messer (1891) A.C. 248 (P.C.).

2s DiCastri, Thom's Canadian Torrens System 290 (2d ed. 1962).

${ }^{26}$ Fox, supra, n. 3 at 491.

27 DiCastri, supra, n. 25 at 291. 
It has often been assumed that this new system was to be imposed upon the general law of real property without altering the latter. ${ }^{28}$ However, it now seems clear that this was neither wholly the intention nor the accomplished fact. Hogg has stated that:29

[a]lthough neither of the extreme statements, i.e. that the law of real property has been revolutionized by the system, and that the system has merely introduced changes in the methods and forms of conveyancing, taken by itself, correctly describes the changes really introduced by the system, yet there is justification for each ....

It is not within the scope of this paper to examine these completely. This point is nevertheless worthy of note, for by it one may appreciate that in analyzing the title registration system many old concepts, and many which are startingly new, must be invoked. For example: ${ }^{30}$

[The] most prominent feature in the ... system - the necessity for registration to the due creation or transfer of any interest in land-which causes the system to approximate to a system of alliodal ownership....

\section{THE HYPOTHESIS}

Now that the framework has been constructed the scenario of the particular problem under analysis must be sketched in. This problem really cannot be simply expressed, but may be approached in these terms: What is the effect of the registration of a transfer of title on that title?

The debate on the answer to that inquiry is old and vigorous. In recent times that most common battleground has been the 1967 decision of the Privy Council in Frazer v. Walker; ${ }^{31}$ but it goes back farther than that. The general pattern which the problem takes is as follows: A person registers an invalid transfer. Does that person obtain, by virtue of the registration, a so-called indefeasible title; or is he subject to the equities of the transfer and thus only being capable, by virtue of his position as registered owner, of giving root of title to a third party transferee?

The former position is often referred to as the theory of immediate indefeasibility; and is expressed in the following terms: ${ }^{32}$

Except to the extent (specified expressly within the Land Titles Act) registration of an instrument will cure defects in that instrument in favour of a bona fide purchaser for valuable consideration who will thus obtain an indefeasible title.

The latter, designated as the theory of delayed indefeasibility, is generally expressed thusly: ${ }^{33}$

The rules of general law relating to the validity of transactions inter partes apply inter partes to transactions with land under the [Torrens title registration system], and registration will not defeat the right of the court in appropriate circumstances to amend the certificate of title until the rights of a third party acting without fraud and for valuable consideration have supervened.

The hypothesis which will be advanced and tested here is that a system of title registration should be concerned with the validity of root

\footnotetext{
28 Frisk v. Robertson (1907) 4 C.L.R. 864 at 871; Barry v. Heider (1914) 19 C.L.R. 197 at 213.

29 Hogg, supra, n. 1 at 77; Woodman, supra, n. 15 at $96,102$.

so Hogg, supra, n. 1 at 3.

31 [1967] 1 A.C. 569; [1967] 2 W.L.R. 411; [1967] 1 All E.R. 649 (P.C.)

32 Woodman, supra, n. 15 at 249.

${ }^{33}$ Id.
} 
of title, and that only. It is suggested that the system should not, in a general sense, concern itself with the validation of deeds inter partes. The validity or invalidity of these latter matters were relatively easy to ascertain. As Torrens himself pointed out, the real defect of land title transfer was the susceptibility of title to past defects-which could be passed on and which made the tedious and treacherous historical deduction of title necessary. It may well be, as will be shown, that in his zeal to expunge the latter, Torrens drafted provisions broad enough to cure defects in deeds inter partes as well. It will be argued, however, that if the former were or is the case, it ought to be now corrected as a source of at least as great a mischief as it was to correct.

Throughout the remainder of this paper it will be urged that an analysis of this (and other) problems will be advanced and clarified if conducted on two levels. What ought first to be done is to examine the defect to see if it goes to the transfer, or to the actual root or source of title-i.e. the registered interest of the transferor. If the defect is of the former variety, the general law of deeds should be applied and the result determined accordingly. If the defect is of the latter variety, on the other hand, the principle of indefeasibility as set out in the Land Titles Act ought to be invoked, rendering the defect ineffective-except as the Act provides to the contrary.

An example may make the concept clearer. Suppose that A, an imbecile, is the validly registered owner of a parcel of land. A executes a transfer to $B$, an innocent party; and $B$ registers the transfer. $B$ now transfers to C. Now, setting aside the question of volunteers us. bona fide purchasers for consideration, the hypothesized approach would proceed as follows: $B$ is entitled to rely on A's title as a valid root on which he may base his own. However, as his transfer is defective (A lacking capacity) B does not acquire good title at any time, nor, in the traditional sense, can he give good title. However, by reason again of the indefeasibility provisions of the Act, $\mathrm{C}$ does not have to ascertain the validity of B's title. The statute creates an indefeasible root in favour of C. As there are no defects in C's transfer, $\mathrm{C}$ acquires good title.

It will be apparent that this has far reaching implications in respect of the registrar's power to correct. In evaluating those implications fully, the current difficulties in drafting as well as the constitutional ramifications, must be considered. It is thus proposed that a total evaluation not be undertaken here; and that the analysis proceed on the assumption that necessary correction could be undertaken by some tribunal-registrar or court-leaving to some future consideration the designation of that tribunal and the means to be employed.

It will be noticed that the method proposed is really an amalgum of traditional conveyancing practice and the Torrens' solution to dependent titles. It has, perhaps, two virtues. Firstly, by supporting the theory of delayed indefeasibility it dispenses with the serious defects of the alternative proposition. These will be discussed at length later. Secondly, it provides what may be a useful conceptual framework for the analysis of some difficult problems and cases. Its application to the case of Kaup v. Imperial Oil Limited et al. ${ }^{34}$ may be taken as an illustration of the latter.

The facts of that case were that the executor of an estate sold a parcel of land to Mrs. Kaup in 1919. The transfer reserved out mines and

34 (1962) 37 W.W.R. 193; 32 D.L.R. (2d) 112; (1962) S.C.R. 170. 
minerals, but in error the new title reserved out only coal. In 1924 Mrs. Kaup transferred the land to herself and her husband-the new title perpetuating the error in reservation. Twenty-four years later the registrar purported to correct the title as the original owner of the mines and minerals had assigned the interests to her children who had executed leases in favour of Imperial Oil Limited.

It was argued in favour of the Kaups that once Mrs. Kaup was registered as owner that the registration provisions of the Act gave her the right to give an indefeasible title. This argument was rejected by the court. It was agreed, however, that although Mrs. Kaup did not have good title to the mines and minerals, a bona fide purchaser for value could have acquired good title to them on the strength of her registered interest.

The obvious question which arises is "What was the nature of Mrs. Kaup's interest?" She is said not to have good title, but yet someone can "get good title from her". Applying the approach suggested, one would say that Mrs. Kaup never did have any interest at all in the mines and minerals, and neither could she give one. However, a registered title, while not conclusive in favour of the registered owner in all respects is, subject to the exceptions within the Act, an indefeasible root of title in favour of a subsequent purchaser. Mrs. Kaup does not give good title; it is granted under the Act if the transfer is validly executed. It is thus suggested that there never is indefeasible title, nor an unimpeachable transfer, but rather simply an unqualified root.

That is the hypothesis. It now remains to test it.

\section{THE TORRENS TRANSFER: THE METHOD}

Those who suggest that in a Torrens system the "register is everything" may, with respect, have omitted a salient fact, viz. that in Torrens' mind and statute it was not. Rather, it was only $a$ part of the system. Professor Thompson has justly warned about the distortion produced by such generalities ${ }^{35}$ and such warning is well taken here. The contents of the register certainly is a central feature of the system, but when introducing his Bill in the South Australian Legislature it was the method, not the result, of registration to which Torrens pointed as the means by which his wonders could be accomplished.

It will be recalled that under the hateful system with which Torrens was so vexed, the key to all evil had been the dependent nature of titles and the possibility of a holder being deprived of his land by a flaw in some previous title. There was, however, one situation in which title was virtually unassailable-when one held on direct and immediate grant from the Crown.

Now the conclusion which Torrens drew from this was very unfortunate, for he appears to have deduced that such was the only way good title could ever be obtained. It seems not to have occurred to Torrens that he could have provided for a conclusive register instead. Instead, observing that good titles under the old system were those on original grants, he set out to dispense original grants on a grand scale. Under his system each land holder was to hold "direct from the Crown"-giving him the same security as such a person had under the English system (although, as will be seen, perhaps a lot less): 36

\footnotetext{
${ }^{35}$ Thompson, supra, n. 12 at 120.

36 Harrison, supra, n. 7 at 126.
} 
Transfers are conducted on the principle ... [of] the existing title being surrendered to the Crown and a fresh title issued from the Crown vesting the estate in the transferee indefeasibly.

Accordingly, it has been fairly observed that "it is not the parties who effectively transfer the land, but it is the state that does so ...."37 For the same reasons it is not correct to refer to title as being given by any person.

To make this approach feasible it was necessary to introduce a second key principle, viz. that to be valid, dealings with land would have to be registered. ${ }^{38}$

Reference has been made to the notion that Torrens could, and perhaps should, have accomplished his object of independent titles by simply "making the register conclusive in favour of the bona fide applicant who first brought land under the Act and the bona fide purchaser who subsequently dealt on the faith of the register". ${ }^{39}$ Evidence has also been adduced that Torrens rejected this approach, in form at the very least, for reasons which may amount to no more than inadvertance born of lack of experience with that conception. His writings indicate, for example, that he thought complete indefeasibility was the logical corollary to the principle of independent title by registration..$^{40}$ Logic can only be found in this if it is first assumed that only by grant can secure title vest. It is this restrictive view which provides much of the conceptual foundation of the Act, and accounts for the wording of the principal indefeasibility provisions of the original Act: ${ }^{41}$

33. Every certificate of title or entry in the register book shall be conclusive, and vest the estate and interests in the land herein mentioned in such manner and to such effect as shall be expressed in such certificate or entry valid to all intents, save and except as is hereinafter provided in the case of fraud and error (emphasis added).

By so restricting the concept, treating registration as an original vesting of interest, and ignoring the alternative conception of good root plus valid transfer, it is suggested that one of the greatest blunders in the system was effected. The concept of registration as a vesting of new title can never (whether it was intended to or not is beside the point) account for the transmission of title subject to trust, or for many of the problems associated with joint and common tenancies. ${ }^{42}$ Any correction of the register must be totally unsound.

Subsequent amendments reduced the original formulation until it became all but extinct. The exceptions to conclusiveness which were first included, and the subsequent introduction of a host more made ludicrous the notion that the certificate represented a new grant: 43

Of course, it might still have been maintained that the certificate operated as a grant, but as a grant which in the specially excepted cases would be wholly or partially invalid. But this would have been an artificial conception and it must have seemed better to abandon the original principle and instead to treat the certificate of title as being what its very name imported, rather than as a grant or source of title.

The suggestion is that the form was dropped. It is certainly not relied

\footnotetext{
37 Adams, Indefeasibility of Land Transfer Title, (1949) 25 N.Z.L.J. 216.

3s Fox, supra, n. 3 at 491.

39 Harrison, supra, n. 7 at 129.

$10 \mathrm{Id}$.

4 Supra, n. 4, 8. 33.

42 Hogg, supra, n. 1 at 765.

43 Harrison, supra, n. 7 at 130.
} 
upon currently. Nevertheless, its influence is still manifest in the wording of some sections of the modern Act (specifically those dealing with the effect of registration) and it is this which renders so plausible the totally needless concept that registration cures all defects-not only of root, but of transfer: 44

65 (1). Every certificate of title granted under this Act . . so long as the same remains in force and uncancelled under this Act, is conclusive evidence . . . that the person named therein is entitled to the land included in the same ... (emphasis added).

\section{STERILITY}

For the title registration system to work at all it is manifestly necessary that all dealings take place on the register. For this reason it was stressed from the beginning that transactions in land must derive their validity from registration. The main operative sterility provision in Alberta's Torrens Act accordingly provides that: 45

[A]fter a certificate of title has been granted for any land, no instrument is effectual to pass any estate or interest in that land ... or to render that land liable as security for the payment of money, unless the instrument shall be executed in accordance with the provisions of this Act and is duly registered thereunder ....

Further reinforcement for this concept is provided by section 63 which, subject to limited exceptions, gives the registered proprietor priority over all unregistered estates. Section 58 provides that registered instruments take priority according to the time of registration-first in time being first in priority - thus rounding out the scheme.

These provisions, and their essential preconceptions, were not stated at all in the first Torrens statute, and were only partially developed in the Act of 1858 . By 1860 the original conception of registration as a grant of title had been dropped (although, as was pointed out, the notion was not entirely extinguished) and the current approach was introduced in the following terms:46

41. Notwithstanding the existence in any other person of any estate or interest, whether derived by grant from the Crown or otherwise, which, but for this Act, might be held to be paramount, or to have priority, and, except in the case of fraud, the registered proprietor of land, or of any estate or interest in land under the provisions of this Act, shall hold the same subject to such encumbrances, liens, estates, or interests, as may be notified, by entry or memorial, on the folium of the register book . . . but absolutely free from all other encumbrances, liens, estates, or interests whatsoever, except the estate or interest of a proprietor claiming the same land under a prior certificate of title, or under prior grant registered under the provisions of this Act, and except as regards the omission or misdescription of any right of way or other easement, created in or existing upon any land, or the wrong description of any land, or of its boundaries.

One does not really have to force his mind to perceive that there was here manifest a movement away from the conception of a new grant at every transfer, towards the more operational and defensible conception of the register as a conclusive root of title by the establishment of interest priorities. As has been pointed out, remnants of the original conception linger in current statutes, but it is of more than passing interest to note the subtle change in emphasis noted here. It is of further significance to note that it was the 1860 Act which also introduced the special

44 The Land Titles Act, R.S.A. 1955, c. 170, s. 65.

45 Harrison, supra, n. 7 at 130.

46 Supra, n. 8, 8. 41. 
protection afforded to the bona fide purchaser for valuable consideration: 47

120. Provided also, that nothing in this Act contained shall be interpreted to subject to any action of ejectment, or for recovery of damages, any purchaser or mortgagee bona fide for valuable consideration, of any land under the provisions of this Act, although his vendor or mortgagor may have been registered as proprietor through fraud or error, or may have derived from or through a person registered as proprietor through fraud or error, whether by wrong description of land, or of its boundaries, or otherwise (emphasis added).

Section 167 of the current Alberta statute is substantially the same.

If the register were only conclusive of title, instead of just conclusive root of title, it is hard to see why protection should have to be given in respect of defects in the vendor's title. Indefeasible title would itself cut these off.

It is suggested that there are thus sections in the statute which have developed from diverging points of view. There is the remnant of the vesting grant conception, as represented by section 65 . This lends credibility to the theory of immediate indefeasibility and prevents analysis by root and transfer. There is secondly the newer concept of the transfer as a conveyance and the register as a source of a purchaser's title- "the existing certificate, bearing the name of a real person, [being] conclusive evidence of his title in favour of any person dealing with him in good faith and for valuable consideration" (emphasis added). ${ }^{48}$

Valiant attempts by the courts have been made to reconcile these provisions; but really, they are not reconcilable. Surely legislative reconsideration is now needed.

Notwithstanding the sterility provisions of the Act and Torrens' hope that there would be one estate in land, it now is firmly established that "as between the immediate parties thereto an unregistered statutory instrument has the same efficacy as any other instrument passing an equitable interest". ${ }^{99}$ This is made express by the statutes of Manitoba and British Columbia, and has been held implicit in the statutes of other jurisdictions. ${ }^{50}$ The weight of authority establishes, however, that these rights do not prevail over subsequent registered owners, and the Act seems clear to that effect. Thus registration remains, in Ruoff's words, "compulsory in the sense, not that a defaulting chargee can be punished, but that it will lose valuable advantages by failing to do that which it may do". 51

\section{THE TRANSFER AS A DEED}

If a transfer may be equated with a deed, that would lend weight both to the delayed indefeasibility theory, and the cogency of analysis by root and transfer. The statutes of the southern Commonwealths have referred to transfers as analogous to deeds, ${ }^{52}$ confirming the trend noted above of not regarding registration as a dispensation of title, but confirmation of title. The Alberta statute, borrowed from the 1861 South

\footnotetext{
${ }^{47}$ Id. 8. 120.

4" Canadian Pacific Railway Co. Ltd. and Imperial Oil Ltd. v. Anton Turta, et al. (1954) 3 D.L.R. 1; 12 W.W.R. 97; [1954] S.C.R. 429 at 452 (S.C.C.).

49 DiCastri, supra, n. 25 at 242.

so Id. at $242-246$.

31 Ruoff, supra, n. 13 at 43.

32 Thom, The Canadian Torrens System 234 (1st ed.).
} 
Australian version (which still referred to a transfer as a memorandum only ${ }^{53}$ ) appears to have thus been fixed at the earlier view. Thom says that in Canada "a transfer is not a deed nor do the Acts profess to give it the effects of one". 54

The earliest clear judicial dictum to this effect in Canada is a statement in the Alberta Supreme Court in the case of Arnot and Smith v. Peterson, ${ }^{55}$ wherein Beck J. stated that: ${ }^{56}$

... a transfer made under the Land Titles Act is not a deed of grant. It does not pass the title, and its practical affect [sic] is nothing more, or at all events, little more than a mere order to the registrar by the holder of the registered title to transfer the title to someone else.

This dicta is not as clear as it might be. What, for example, is a deed of grant? At any event, it is suggested that statements such as this do not, in their proper context, derogate from the general application of the law of deeds at all. Although this case refused to apply the rule that deeds cannot be signed in blank to a transfer under the Torrens System, subsequent cases have, for other purposes, applied the general law of deeds-in effect if not in form.

For example, the Privy Council in the case of Knight Sugar Co. v. Alberta Railway \& Irrigation Co. ${ }^{57}$ after referring to the principle expressed by Beck J., stated that it could not be accepted: ${ }^{58}$

From the language used in these sections (the equivalent of sections 56 and 57 in the

Alberta statute) it seems clear that ... the transfers ... should become operative ....

It is the transfer which, when registered, passes the estate or interest in the land: and it appears, for the purpose of the application of the doctrine in question (i.e. the doctrine of merger) to differ in no relevant respect from an ordinary conveyance of registered land.

The most charitable interpretation, from the point of view of the Arnot dictum, is that in some areas of the law (the doctrine of merger in this case) the courts will apply the law of the effects of deeds. A more plausible view, derived from a reading of the passage as a whole, is that a transfer is to have a vitality and force of its own. With a vitality of its own, a fortiori it may have defects of its own.

The best view is likely that expressed by Hogg. "The Statutes do not make such instruments 'deeds" " he has written, "but only gives them, when registered, the effect of deeds". ${ }^{99}$ This implies, as it should, that transfers are susceptible to many of the same deficiencies as deeds at common law. If they have the effects of deeds, they have the liabilities of deeds. Woodman has pointed out that the decision of the Privy Council in Gibbs v. Messer ${ }^{60}$ is based on the view that: ${ }^{61}$

... the legislature in granting indefeasibility to a registered title was contemplating that registration would be effected persuant to the lodgement of genuine instruments, so that the Act would be construed consistently with the general principles of common law....

There seems no reason for supposing that the legislature would have

\footnotetext{
53 Hogg, supra, n. 1 at 24.

st DiCastri, supra, n. 25 at 362.

ss (1912) 2 W.W.R. 1 (Alta. S.C.)

so Id. at 2.

57 (1938) I All E.R. 266: (1938) I D.L.R. 321 (P.C.).

$58 \mathrm{Id}$. at $324,325$.

59 Hogg, supra, n. 1 at 908.

${ }^{60}$ Supra, n. 24.

61 Woodman, supra, n. 15 at 101.
} 
contemplated securing registration by invalid instruments. Indeed, section 199 of the Alberta Land Titles Act provides for a representative to execute a transfer for a person of unsound mind. The implication may be drawn that a transfer executed personally by a person with such deficiency might be defective. Hogg says that:62

[The] improper execution of an instrument purporting to pass the interest of a registered proprietor who was under disability, as of infancy or lunacy, would confer no more interest than any other improperly executed instrument.

Notwithstanding this, there is a line of authority-which it was suggested has been made possible by Torrens' original misapprehension of method and now perpetuated in an irreconcilable statute-which holds that registration confers an unassailable title upon the registered holder. This is said to cure all possible defects in the transfer. It is submitted that this is a very unfortunate view, and that it is preferrable to regard registration as making a void transfer valid. It is to this that attention will now be directed.

\section{INDEFEASIBILITY OF TITLE: THE MYTH}

The term "indefeasible" is foreign to the Land Titles Act itself. It is nowhere to be found in most of its many versions. The principle to be represented by that term has been developed by the cases, and also confused therein until the two widely divergent theories previously mentioned have developed. Representations of both may be found in the case of C.P.R. v. Turta. ${ }^{63}$ The following expresses the concept of immediate indefeasibility: 64

The cardinal principle of the statute is that the register is everything and that, except in cases of actual fraud on the part of the person dealing with the registered proprietor, such person, upon registration of the title under which he takes from the registered proprietor has an indefeasible title against all the world.

This was in the judgment of Estey J. The deferred indefeasibility theory is found in the judgment of Rand J. in the same case: 65

The general and primary conception underlying the statute, as it is of all legislation establishing what is known as the Torrens system of land titles, is that the existing certificate, bearing the name of a real person, is conclusive evidence of his title in favour of any person dealing with him in good faith and for valuable consideration.

The application of the two approaches did not result in a conflict of conclusions on the particular facts of that case, but the significance of the difference is nevertheless extreme. If the theory of delayed indefeasibility is correct, the register is conclusive root of title only, and a purchaser must take his title by a valid conveyance. Following that reasoning title is not indefeasible, because it can be challenged on the basis of an ineffective transfer-as in Gibbs v. Messer. ${ }^{66}$ If the theory of immediate indefeasibility is correct, a registered owner's title can be challenged on neither root nor transfer; but a registered owner is still not secure as he can be deprived of his land by a totally invalid transfer executed by a third party-as in Frazer v. Walker. ${ }^{67}$ All of this

\footnotetext{
62 Hogg, supra, n. 1 at 911.

63 Supra, n. 48.

64 Id. at 443; citing Fels v. Knowles 26 N.Z.R. 604 at 620.

cs Id. at 452

66 Supra, n. 24.

o7 Supra, n. 31.
} 
is in addition to the express exceptions to indefeasibility found in the Act. No matter how it is examined, indefeasibility of title is a myth.

An analysis of the cases is essential to an appreciation of the law as it now stands. Most of the cases have their origin in New Zealand and Australia where the majority of the litigation on the Torrens system has taken place; and it is also from these that most Canadian cases dealing with indefeasibility have taken their lead.

The earliest case which is clearly on point is that of Ex parte Davy. ${ }^{68}$ (Jonas v. Jones ${ }^{69}$ in 1883 has been suggested as an even earlier case, ${ }^{70}$ but it is here suggested with respect that although the fact situation could have given rise to a test of the principles of conclusiveness of title, the judgment was rather narrowly confined to application of an equitable jurisdiction.) In the Davy case Williams J. gave judgment in language unambiguously requiring the registration of a valid transfer. Considering the alternative he added: ${ }^{71}$

If we were to decide that a proprietor duly registered under the Act could be summarily ejected from house and home by a person who founded his claim solely and directly on the forgery of the proprietor's own name, our decision would not only be contrary to natural justice but would tend seriously to affect the security of titles.

The next significant case is the decision of the Privy Council in Gibbs v. Messer, ${ }^{72}$ an appeal from Australia. In that case a third party had forged and registered a transfer naming a non-existent person as transferee and eventually registered owner. He then purported to execute a mortgage in favour of one McIntyre, acting as agent of the (fictitious) registered owner. Messer, the prior registered owner, then went to law and sought, successfully, to have the mortgage set aside. Some have felt the case ambiguous because of the heavy reliance in some dicta on the presence of a fictitious person: ${ }^{73}$

The McIntyres cannot bring themselves within the protection of the statute .... The result is unfortunate, but is due to their having dealt, not with a registered proprietor, but with an agent and a forger, whose name was not on the register, in reliance upon his honesty.

Indeed, the case has been distinguished on this ground. ${ }^{74}$ However, the principle which was applied to the facts-aside from what the facts themselves were-seems eminently clear: ${ }^{75}$

\begin{abstract}
Although a forged transfer or mortgage, which is void at common law, will, when duly entered on the register become the root of a valid title, in a bona fide purchaser by force of the statute, there is no enactment which makes indefeasible the registered right of the transferee or mortgagee under a null deed.
\end{abstract}

Until this point, then, there is probably conformity among the cases. It is the 1905 decision of the Privy Council in Assets Co. v. Mere Roihi, ${ }^{76}$ an appeal from the New Zealand Court of Appeal, that is said to introduce the divergence of thought. The essentials of the facts of this case are that a group of Maoris claimed that their land had been taken from

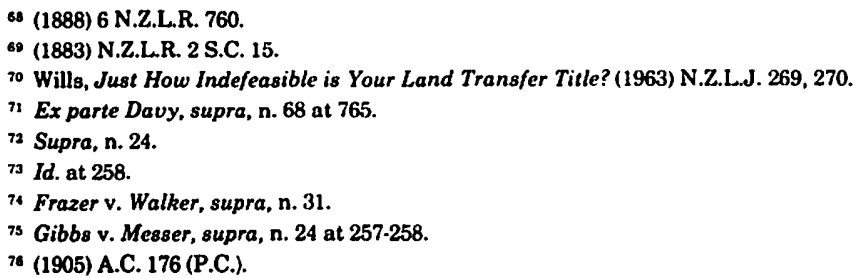


them by use of fraudulent documents; and through them had passed by a series of valid transactions to the Assets Co., a bona fide purchaser. The Maoris based their claim on the old maxim, appropriate under a system of dependent titles: nemo dat quod non habet. In response, their Lordships stated: 77

The sections [of the Land Titles Act] making registered certificates conclusive evidence of title are too clear to be got over.

The meaning of the Board in this rather cryptic statement may become clear when one considers the question to which it was addressed; and especially when it is expressly stated to be the equivalent of the judgment of Williams J. in the court below. Williams J., it will be remembered, clearly enunciated the principle of delayed indefeasibility in Ex parte Davy. ${ }^{78}$ Surely then there is not so much cause to be found here for supposing that a new principle was introduced.

Another passage, however, lends support to consideration of the Assets case as authority for the proposition that registration of a defective instrument cures all defects: ${ }^{79}$

A person who presents for registration a document which is forged or has been fraudulently or improperly obtained is not guilty of fraud if he honestly believes it to be a genuine document which can properly be acted upon.

In reality, however, this passage is directed to the Maoris argument that by presenting a claim for registration which was based on an earlier defective title, the Assets Co. was guilty of equitable (constructive) fraud. The passage quoted is simply the Board's rejection of such an application of fraud in these cases. Although the passage at first reading seems ambiguous, when read in light of the issue it becomes clearer.

Despite these explanations, however, the Assets Co. decision has been taken as authority for the principle of immediate indefeasibility in the case of Boyd v. Mayor, Etc. of Wellington,,$^{80}$ and through that case by the Privy Council in Frazer v. Walker. ${ }^{81}$

Before the latter cases are fully considered, however, it will be useful to turn to an alternative ground on which the plaintiffs in the Assets case based their claims as it will throw light on what is to follow.

Exercising a certain amount of ingenuity the plaintiffs contended that the registered owner was in law holding the land as a constructive trustee for the "actual owner", who had been deprived by fraud. This argument was perhaps derived from the decision of Williams J. in Mathews v. Paraone. ${ }^{82}$ In that case a proprietor who had been improperly registered was compelled to hold the land he had thus obtained, as constructive trustee for the true owner until the rights of a third party bona fide purchaser for value might intervene. The qualification added to the principle of the trusteeship obviously removes the Assets case from its application. Any suggestion that the Assets case has tacitly rejected the rule in the Mathews case ${ }^{83}$ is thus open to doubt. In rejecting this argument of the plaintiff it is far more likely that the Board was

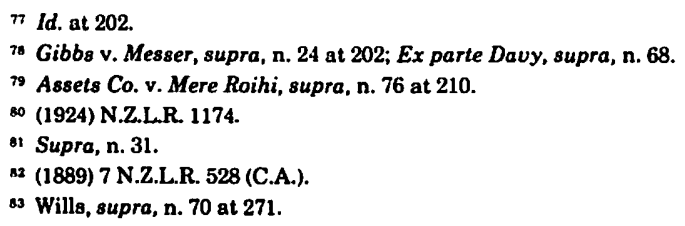


condemning the notion that a court could impeach a Torrens title for any cause previously available under the jurisdiction of equity $-a$ view expressed in Solicitor General v. Mere Tini ${ }^{84}$ wherein Williams J., otherwise approved, seemingly went too far.

That equitable jurisdiction was never intended by this to be extinguished altogether (which critics of the Mathews decision must come close to suggesting), even by the immediate indefeasibility concept, is apparent from the judgment in Frazer v. Walker wherein their Lordships: 85

... wish to make it clear that this principle [immediate indefeasibility] in no way denies the right of a plantiff to bring against a registered proprietor a claim in personam, founded in law or in equity, for such relief as a court acting in personam may grant.

It is not within the scope of this paper to develop fully the implications of that statement. It certainly leaves open the possibility of redress for such wrongs as breach of trust-express or constructive. Suffice it to be said in addition, that taken to its logical fulfilment as an exception to immediate indefeasibility, it accomplishes indirectly and deviously what delayed indefeasibility accomplishes directly and clearly, for: 86

[I]t may be laid down as a principle of general application that where the rights of third parties do not intervene no person can better his position by doing that which it is not honest (in an equitable sense) to do.

Certain it is that the full implications and limits of this doctrine have not been defined. ${ }^{87}$

Returning to the main principles, it is now left to briefly survey those cases which followed the Assets decision. In Boyd v. Mayor, Etc., of Wellington 88 the New Zealand Court of Appeal, by a majority of three to two, accepted that case as conclusive of the immediate indefeasibility theory. The issue in Boyd's case was whether an expropriation of land by a void Municipal Proclamation could be validated by registration. True to the principle that the register is everything, the majority held that the defect was cured. However, a strong dissent by Salmond J.- to the effect that "an instrument which is null and void before registration remains equally null and void after registration"89 was accepted in the later Australian case of Clements v. Ellis. ${ }^{90}$ Thus the question was not finally settled. Further, one wonders as to the constitutional implications of the Boyd view in Canada.

The next, and final, case of real significance is that of Frazer v. Walker.91 In that case a mortgage in favour of Radonskis was executed and registered as encumbering land of which $\mathrm{Mr}$. and Mrs. Frazer were registered owners. Mrs. Frazer had placed her signature on the form, and forged that of her husband. She then defaulted on the mortgage, and Radonskis sold the land to Walker. Radonskis and Walker acted

\footnotetext{
ot (1889) 17 N.Z.L.R. 773 (C.A.); Assets Co. v. Mere Roihi, supra, n. 76 at 205.

as Supra, n. 31 at 585.

so Dillican v. West (1921) N.Z.L.R. 617.

37 A comprehensive analysis of this problem is given by Stevens, The In Personam Exceptions to the Principle of Indefeasibility, (1969) 1 Auk. L. Rev. 29.

Supra, n. 80 at 256 .

so Id.

00 (1934) 51 C.L.R. 217 (Aust. H.C.).

92 Supra, n. 31.
} 
throughout in good faith. Mr Frazer sought a declaration that the mortgage was a nullity, or that his interest in the land was not affected, and that the register be corrected accordingly.

It is clear that on these facts whichever theory is used-that of delayed or immediate indefeasibility-the result will be the same. That is because a third party, bona fide and for valuable consideration, has intervened and taken an interest by valid transfer. Under either approach he is entitled to rely on the register. However, the Privy Council went further than the facts of the case required and considered what the plaintiff's rights would have been against Radonskis had a bona fide third party purchaser not intervened. The Board held that, aside from the in personam exception noted above, the plaintiff had no rights at all. The judgment is clear authority for the theory of immediate indefeasibility - so clear that Professor Woodman has suggested that "the ghosts of deferred indefeasibility have ... been finally laid to rest". ${ }^{92}$

However the decision, as noted, is purely obiter. It is based upon a tenuous distinction of Gibbs v. Messer on the basis of the fictitious third party-as discussed above-as well as the dubious authority of the Assets and Boyd cases. Also, the authority of the Privy Council does not reach to Canada, where our "ghosts" may roam free from the supervision of Her Majesty's judicial advisors. Historically, the great weight of authority in this country has been in support of deferred indefeasibility as it is expressed in Gibbs v. Messer ${ }^{93}$ As recently as 1963 the British Columbia Court of Appeal in the case of Credit Foncier v. Bennett ${ }^{94}$ affirmed its support of that principle. Although Frazer v. Walker has not received express consideration in this country yet, there is no reason to believe that it will overturn this long tradition of support. Of course, it would be far better to amend the statutes so as to have a clear and workable legislative statement of the principle.

\section{$X$. WHERE THE PREFERENCE LIES}

It has been the object of this paper to show that analysis of transactions in land by means of root and transfer, incorporating the principles of deferred indefeasibility, is a plausible technique under Torrens legislation. To this end statute and case law on the subject has been presented, with submissions that it lends credence to that proposition. It has been suggested that although Torrens' early views most probably contemplated immediate indefeasibility, this likely stemmed from a misapprehension of the methods open to him. It was then pointed out that although the early provisions have not been totally expunged from the Act, later amendments favour the delayed approach. It was further suggested that many of the ambiguities in the Alberta statute result from an adoption of the Australian Act while still in the transitional stage; and that amendment was accordingly needed.

Attention was then turned to the cases in which the respective theories of immediate and delayed indefeasibility were developed and

\footnotetext{
92 Woodman, supra, n. 15 at 96.

93 Watson v. Ogilvie (i924) I D.L.R. 815; (1924) 1 W.W.R. 837; 18 S.C.R. 69 (Sask. K.B.); McKinnon v. Smith (1925) 4 D.L.R. 262; (1925) 3 W.W.R. 290; 35 Man. C.R. 209 (Man. C.A.); Dallas v. Toronto General Trust (1936) 3 W.W.R. 219; (1936) 4 D.L.R. 233; 44 Man. C.R. 320 (Man. K.B.); Shorey v. L. \& Winnipeg District Registrar (1938) 2 W.W.R. 346; (1938) 3 D.L.R. 534 (Man. K.B.); Lichtbuer v. Dupmeir (1941) 3 W.W.R. 64 (Sask. K.B.); Essery v. Essery (1948) I D.L.R. 405 (Alta. A.D.); Boychuk v. Perry (1948) 2 D.L.R. 406 (Alta. A.D.); Canadian Superior Oil v. District Registrar (1952) 5 W.W.R. 686; (1952) 3 D.L.R. 773 (Man. Q.B.).

94 (1963) 43 W.W.R. 545 (B.C.C.A.).
} 
discussed. It was suggested that ample judicial authority for the latter could be demonstrated; but that there was a clear conflict of authoritypointing again to the unsatisfactory state of the Act and the need for amendment.

Attention must now be turned to the question of whether, aside from facility of analysis which it provides, there is any preferential merit in the theory of delayed indefeasibility.

Two of the prime needs of a transfer system are speed and simplicity. Is immediate indefeasibility necessary for their accomplishment? There is little doubt that the preparation and execution of almost any transaction could be speeded up if there were no consequences to error. If the state were to guarantee all of the dealings of society, the time lost in care could thus be saved. However, the cost to society in indemnifying the rights which were lost in the course of the slip-shod methods which would certainly result would be extravagant.

As has been said many times over, the defect of the old system of real property transfer was the dependent nature of titles. This can be easily remedied without total indemnification by simply guaranteeing root of title, while leaving the dealings to the care of the parties. Further, Taylor points out that "only this approach preserves the valuable accumulation of legal wisdom and procedures for establishing and enforcing the rights between parties on transfer of property" 95 (emphasis added).

In addition to thus going beyond the demands of justice a system of conclusively guaranteed titles actually places security of title in jeopardy. As is illustrated by Frazer v. Walker an innocent party may be deprived of his land by an instrument not of his making, and nothing short of continuous scrutiny of the register, by him, can prevent it. This doctrine completely undermines security of title and in doing so creates a mischief at least as serious as that which the Land Titles Act was designed to remedy. Taylor has illustrated this by pointing out that certificates of title have thereby become more negotiable than an order cheque-which at least requires a valid endorsement. The business necessity which requires easy passage of the latter is certainly not required for land titles, where some element of security is essential. ${ }^{96}$ It is by operation of delayed indefeasibility that both security of title and transfer is achieved.

Immediate indefeasibility further does not square with the principle of in personam exceptions, as discussed above, nor with the corrective powers of the registrar in situations other than the express statutory exceptions.

Thus, the preferred security for a Torrens system to give is not a guaranteed title-for that is manifestly impossible in all situations; rather the object should be a guaranteed root of title, which can be given to all. ${ }^{97}$

\section{THE PREFERRED PARTY}

Before turning to a consideration of the nature of the amendments which could be made to the Land Titles Act, brief consideration should

95 Taylor, How Indefeasible is Frazer v. Walker?, (1970) 44 Aust. L.J. 248 at 250.

* Id. at 251.

97 Id., passim. 
be given to the question of whether indefeasible root is available to all takers or only bona fide purchasers.

There seems to be a predilection in this area of the law for theories, and there are two to consider here. The first, sometimes referred to as the bona fide purchaser theory, holds that the indefeasibility provisions of the Act apply only to bona fide purchasers for value-against volunteers the equities of the transaction apply. ${ }^{98}$ The second view, the so-called absolute theory, goes farther and extends the indefeasibility provisions to volunteers also..$^{99}$ It has been suggested that the only difference between the two is that the latter goes farther; and that they are not really opposed. ${ }^{100}$ With respect, however, it must be pointed out that the absolute approach is akin to the theory of immediate indefeasibility in that both rely on the conclusiveness of the register. Indeed, in its pure form the absolute theory seems to presuppose immediate indefeasibility (although the converse is not necessarily true).

It is submitted that the absolute theory is not to be preferred. It cannot account for the special protection given to bona fide purchasers by such provisions as section 167 of the Alberta statute which, as part of the move away from Torrens' original concepts towards delayed indefeasibility, renders such protection necessary. There is need here too for statutory clarification in what is essentially a policy decision. It has been suggested that protection ought not to be extended to volunteers as they do not expend money for the title and thus do not stand to lose thereby. It is not beyond the realms of possibility, however, that a volunteer may expend large sums of money on improvements to the property (very much like Torrens' friend) without being within the ambit of proprietary estoppel. In such a case the volunteer would lose his expenditures as well as the land.

\section{REFORM}

In light of all that has been said, it would appear that statutory reform in two specific areas is needed. First, the principal indefeasibility section should be amended so as to clearly state that a certificate of title is indefeasible as root of title only. A transfer should be specified to operate as a conveyance only-without modifying the sterility provisions.

In this connection, Taylor has indicated that the designation of a transfer as akin to a conveyance renders it liable to many types of invalidity of varying degrees of seriousness - not all of which may be susceptible of the same remedy. In New Zealand the problem has been referred to a Commission to classify the potential defects and work out clear and appropriate treatment of each. ${ }^{101}$ That may be a desirable approach here also.

The Alberta Draft Act (1965) ${ }^{102}$ has not had its principal indefeasibility section shorn of terminology tending to the conclusion that registration is conclusive title. ${ }^{103}$ Neither is the true effect of the transfer clearly delineated in the manner suggested. ${ }^{104}$

\footnotetext{
98 See e.g., Royal Bank of Canada v. Esakin (1924) 2 W.W.R. 33 (Sask. C.A.).

.0 See e.g., Coventry v. Annable (1911) 2 W.W.R. 816 (S.C.C.).

100 Thom, supra, n. 52 at 162.

101 Taylor, supra, n. 95 at 254-55.

102 The Real Property Act-A Draft Bill (1965), Alberta.

${ }^{103}$ Id. 8. 1.2.11.
} 
The second area of needed reform is in respect of the relative positions of the bona fide purchaser and volunteer. Their positions should be delineated by an express statement. There appear to be three alternatives: that indefeasible root be available to the bona fide purchaser totally and the volunteer totally; to the volunteer not at all; or to the volunteer in part-protecting him in respect of expenditures made bona fide on property of which he was registered owner. A possible technique would be to establish the limits of the indefeasible root, and then to designate its application to the various classes of successors in title. In this connection some attention should also be directed to the existence and effect of in personam exceptions and remedies.

The Alberta Draft Act (1965) expresses a clear preference for the bona fide purchaser approach. ${ }^{105}$

\section{CONCLUSION}

This has been a long and a complex road, from beginning to end. It is hoped, however, that the wisdom and learning of those who have written before will have been profitably passed along, and that the ideas here presented will not be found unworthy of all attention. This analysis, of course, does not purport to be a final answer; but no doubt rather proves the observation of Baggott that: ${ }^{106}$

... the burning ideas of young men are often wrong, and always incomplete.

-ROBERT B. WHITE*

304 Id. 8. 1.2.22.

105 Supra, n. 102.

100 Baggott, Constitutional History of England (1867).

- B.Comm., LL.B. (Alta.); member of the Alberta Bar Edmonton, member of the firm of Bishop \& McKenzie. 